\title{
Associating Sound with Food in the Antillean Grackle, Quiscalus niger brachypterus Cassin, 1867 (Aves: Passeriformes: Icteridae) ${ }^{1}$
}

\section{Raúl A. Pérez-Rivera ${ }^{2}$ and Alberto Molina-Opio ${ }^{3}$}

\begin{abstract}
The Greater Antillean Grackle, Quiscalus niger brachypterus, is one of the most common birds in urban habitats in Puerto Rico. This species is considered omnivorous and has an ample diet. The bird is quite opportunistic on its feeding habits and foraging patterns. From 2012-2014, while conducting work in a sorghum and corn field in the municipality of Santa Isabel, we observed the Antillean Grackle appear in multiple times just minutes after a plowing tractor had begun its work. It seems that the bird has learned to associate the noise produced by the vehicle with food exposure, as while plowing the machine will stir up a large variety of invertebrates and vertebrates from the soil. After Hurricane Maria, at the municipalities of Caguas, Juncos, and Humacao, we noticed that grackles have apparently learned to associate the noise produced by gas lawn mowers and trimmers with food, as those machines expose, injure, and kill many small animals which are part of the grackle's diet in urban areas. At Caguas and Juncos, grackles waited until the gardeners finished their work to begin feeding on lawns, while at Humacao, grackles have been observed following gardeners using the machines, probably because of the absence of other potential urban predators. The Antillean Grackle seems to be an opportunist innovator with great ability to solve problems. A total of 19 innovations are reported on the genus Quiscalus, making it the second most innovative passerine genus after Corvus, in North America.
\end{abstract}

Resumen: El Mozambique, Quiscalus niger brachypterus, es uno de los pájaros más comunes en hábitats urbanos en Puerto Rico. La especie es considerada omnívora y tiene una dieta amplia. El ave es sumamente oportunista en sus hábitos alimentarios y patrones de forrajeo. De 2012-2014, mientras trabajábamos en un sembradío de sorgo y maíz, en el municipio de Santa Isabel, observamos en muchas ocasiones a mozambiques aparecer minutos después, que un tractor comenzaba a arar. Todo parece indicar que las aves aprendieron a asociar el ruido que produce la máquina, con la exposición de alimentos, mientras el arado levanta del suelo una amplia variedad de vertebrados e invertebrados. Luego del huracán María, en los municipios de Caguas, Juncos y Humacao, notamos que los mozambiques habían aprendido a asociar el ruido producido por podadoras y recortadores manuales de grama con la exposición, de organismos de los cuales se alimenta el ave en áreas urbanas. En Caguas y Juncos, las aves esperaron que los jardineros terminaran su trabajo, antes de invadir el césped, mientras que en Humacao, los mozambiques seguían a los jardineros, probablemente debido a la ausencia de otros

\footnotetext{
${ }^{1}$ Submitted on June 13, 2020. Accepted on June 25, 2020. Last revisions received on August 1, 2020.

${ }^{2}$ Department of Biology, University of Puerto Rico, Humacao, Puerto Rico 00792. E-mail: raperezrivera@yahoo.com.

${ }^{3}$ Department of Education of Puerto Rico, P. O. Box 190759, San Juan, Puerto Rico 00919-0759. Email: amolina197896@gmail.com .
}

DOI: 10.9784/LEB8(2)PerezRivera.01

Electronically available on August 31, 2020. Mailed on August 31, 2020. 
depredadores potenciales. El mozambique es un ave oportunista, innovador con gran habilidad para resolver problemas. Un total de 19 innovaciones han sido reportadas en el género Quiscalus en Norte América, siendo luego del género Corvus, el segundo paseriforme más innovador en patrones de conducta.

\section{Introduction}

The Greater Antillean Grackle, Quiscalus niger (Boddaert, 1783), occurs from the Cayman Islands (except Cayman Brac), throughout the Greater Antilles, including the island of Vieques, in Puerto Rico (Raffaele et al. 1998, Keith et al. 2003). Six subspecies of $Q$. niger are recognized, including $Q$. n. brachypterus Cassin, 1867 from Puerto Rico (Gill and Donsker 2019). In Puerto Rico, this bird is known by many names including mozambique (the official name) and the most common, chango.

This blackbird with yellow eyes has an ample distribution in Puerto Rico and can be seen in almost every habitat except in dense internal forests (Oberle 2010). It is one of the most conspicuous species in urban habitat and usually it is observed in groups (Rivera-Cianchini and Mojica Sandoz 1981, Oberle 2010). The species is considered omnivorous and has an ample diet (Wetmore 1916, Pérez-Rivera 2000). Lack (1976) already noticed that, in Jamaica, these birds were quite opportunistic on their feeding habits and foraging patterns. Ducatez et al. (2015) have found that grackles are highly intelligent and easily learn how to get access to food. Overington et al. (2009) makes the genus Quiscalus the second most innovative passerine genus after Corvus in North America. While Lefebvre et al. (2016) considered the Icteridae second in its capability to innovate in a ranking of bird families within the clade of oscines, or songbirds, with easily visible nine primary feathers.

This work reports casual observations in our neighborhoods, at Bairoa Park, Caguas (from this point forward referred to as Bairoa), Jardines de Ceiba Norte, Juncos (from herein on, Juncos), the campus of the University of Puerto Rico in Humacao (herein abbreviated, UPRH), and 3rd Millennium Genetics (referred to as 3MG), which is located at the Alomar Farm, Road $1 \mathrm{~km}$. 101.7, Santa Isabel. The first three localities have been described in literature (Pérez-Rivera 2000, $2018,2019)$. Santa Isabel is a coastal municipality, about $27 \mathrm{~km}$ from Ponce. The Alomar Farm is part of the coastal plain, rich in organic soil which is planted with experimental seeds, particularly of sorghum and corn.

In the years 2012-2014, while conducting an assessment of the possible impact of wind turbines on birds in a sorghum and corn field at $3 \mathrm{MG}$, many times we observed Cattle egrets, Bubulcus ibis (Linnaeus, 1758), and Antillean Grackles to appear just minutes after a plowing tractor have begun its work. The birds followed the tractor and consumed the earthworms, insect (beetle larvae), spiders (small tarantulas), centipedes, and even pieces of reptiles, and other unidentified animals that were stirred up, injured, or otherwise compromised by the plow. 
In addition, at $3 \mathrm{MG}$, tractors were used to fumigate corn fields. Fifteen to thirty minutes after the tractors had operated, grackles entered the corn fields, apparently to feed on dead insects. We did not notice grackles following other vehicles used to transport workers, equipment, and material to different parts of the farm. Similar observations have been done by agronomist Raúl PerezRodríguez, who used to visit regularly similar farms in southern Puerto Rico, as part of his work.

After Hurricane María (September 20, 2017), grackles were observed more frequently to steal dog food from yards, capture more lizards and break more plastic bags to get access to human leftovers, than previously before. In addition, a novel way to get access to food was observed. Three weeks after the hurricane, it was noticed at Bairoa, that grackles had apparently learned to recognize the noise produced by gas trimmers and lawn mowers and associate the sound with food. When the first author's neighbor began mowing his lawn, and while he was talking to him, he noticed that grackles began arriving, and eventually form an aggregation of $12-15$ individuals. The grackles were perching on the roof of his home and on top of his mango tree, Mangifera indica L. (Anacardiaceae). Immediately after he finished cleaning his lawn, the grackles descended to the yard and began foraging. A week later, the first author cleaned his lawn and observed the same behavior. Then he began observing the neighborhood. On eleven occasions (from 7:00 a.m. to 5:24 p.m.), it had taken an average of 5.5 minutes (range 2-12 minutes) for grackles to begin arriving after a mower or a trimmer was on. Mowers and trimmers, exposed, injure, and kill many invertebrates (mainly insects) and vertebrates (e.g., lizards and frogs) living and hiding in the grass, and the grackles were observed feeding on these. Apparently, the birds discriminated between the noise produced by trimmers and mowers from the one produced by gas generators, used after the hurricane, as at least in Juncos and Bairoa, as grackles were not observed to be attracted to the noise produced by these other machines during the same period of time. We have not noticed open vehicles, carrying mowers and trimmer, to be followed by the grackles or attracted by people just hand cleaning their lawn or gardens. On June 19, 2020, both in Juncos and Bairoa, we conducted a little experiment, exposing trimmers in our lawn and it alone did not attract grackles.

In mid-October 2017, the first author arrived at the Humacao campus of the University of Puerto Rico (UPRH) at about 6:30 am and began examining the trees near the biology building for bird nests and although some bananaquits Coereba flaveola portoricensis (Bryant, 1866), were observed, no grackles were noticed. Fifteen minutes later, the gardeners arrived at the locality. No birds were observed following the golf cars used to carry the trimmers on top of these. With the ignition of a third grass trimmer, the noise was dreadful, and minutes later the grackles began to appear. At UPRH, the grackles were not waiting the gardeners to finish their work. Instead, they were following the gardeners as it passed the trimmer (Figure 1A). 
At the UPRH, on February 20, 2020, in fifteen minutes (from 7:10 to 7:25 am), a group of 11 grackles were able to ingest 19 food articles, mainly pieces of arthropods, on a freshly trimmed lawn. At Bairoa, the grackles did not wait passively for the person cleaning a lawn to finish his job. Instead, they began to forage on nearby yards or vegetation while waiting for the gardener to leave the place. Approximately 2-10 minutes later, after the person had finished cleaning his/her yard and left, the grackles began to move to the cleaned area to forage (Figure 1B). While commenting this behavior to the second author, he began observing the same behavior at Juncos. One of our colleagues, Rafael Muller, also noticed this behavior in Juncos while using a gas mower to clean its yard.
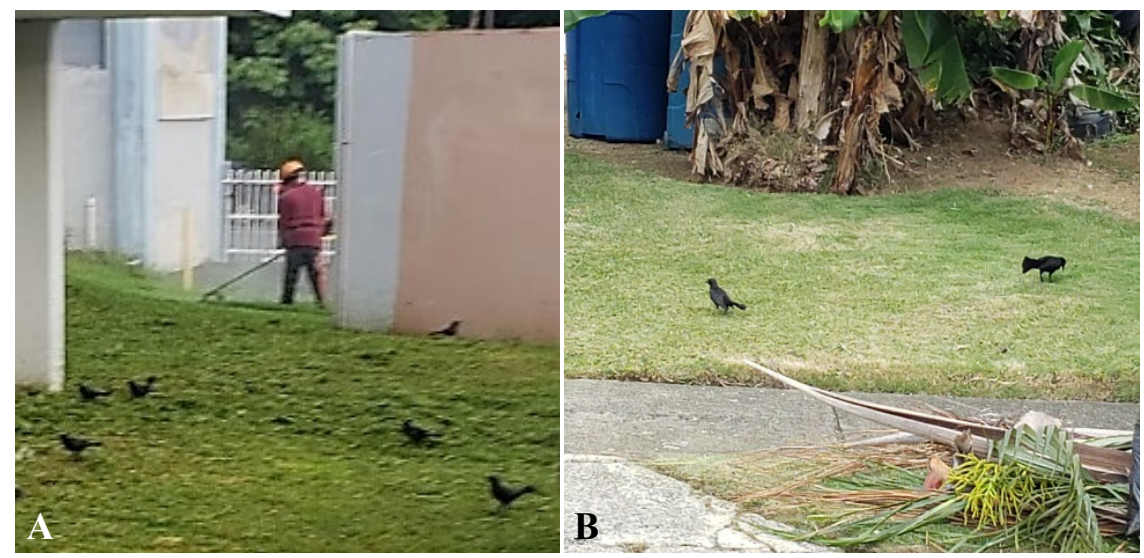

Figure 1. Grackle foraging at recent cut lawns. A. Grackles following a gardener using a trimmer at UPRH. B. Two Grackles feeding on a lawn just cleaned with trimmers at Bairoa Park, Caguas. Photo taken June 12, 2020 at 10:09 am, ten minutes after the gardeners left.

Associating noise or machines with food does not seems new, at least for the Antillean Grackle. Danforth (1926) reported that when cane fields were plowed, flocks of grackles were seen following the plow, eating immature and adult insects as they became exposed. Nevertheless, Danforth (1926), did not mention anything regarding birds learning to associate the tractor with food. Associating the noise of mowers and trimmers with food, may be a more recent learned behavior on the grackles, since these machines, particularly trimmers, are more recent inventions.

In urban areas, the Antillean Grackle flock to forage in newly mowed grass. Mowers and trimmer, expose, injure, and kill many invertebrates (mainly insects) and vertebrates (e.g., lizards and frogs) living and hiding in the grass. Thus, some potential benefits to the behavior exhibited by the grackles are an increase in prey capture and foraging in an environment with fewer visual obstructions allowing grackle predators to be detected easier (Vickery et al. 2001, Deveraux et al. 2006). In Bairoa, grackles, apparently, did not follow the gardeners probably due to these 
moving back and forth with the mowing equipment, in small patios, and because, almost every neighbor has a dog, or a cat which are potential predators.

Birds tend to be visual foragers. As suggested by one of the reviewers, grackles may be using other clues (including visual), to get to places were equipment is used to plow or clean gardens. Although we do not discard that possibility, we do not have any evidence to support this hypothesis. An alternative hypothesis, however, is that grackles may also be using olfactory clues to get to plowed and mowed areas. It is well known that the movement of soil while plowing, releases a distinctive smell (e.g., geosmin) as well as cut fresh grass (e.g., cis-3-hexenal), and these scents attract some animals (Schnee et al. 2006, Chater 2015). In the case of grasses, like maize, the scent also attracts natural enemies of the plant herbivores (Schnee et al. 2006). Although the sense of smell on birds have been debated, new evidence tends to support that scent could be used to navigate, forage, recognition of predators and even to distinguish among individuals (Amo et al. 2007, Steiger et al. 2008, Mardon et al. 2010, Pollonara et al. 2015). Thus, there is the possibility that the grackles may be using a combination of stimuli to get to placed were food is being exposed by machines.

Studies in the field and in captivity have documented the opportunism, innovativeness, and problem-solving abilities of close species such as Quiscalus lugubris (Readers et al. 2003, Morand-Ferron et al. 2004, Morand-Ferron and Lefebvre 2006). A total of 19 innovations are reported on the genus Quiscalus, making it the second most innovative Passerine genus after Corvus, in North America (Overrington et al. 2009). In birds, many of these new behaviors are observed on islands and in urbanized habitats (Reader et al. 2003), which encompass the Antillean Grackle's habitat in the island of Puerto Rico. Finally, this species usually feed in groups. Large groups (up to 35 individuals), were usually observed after Hurricane María. Birds that forms large groups seems to be more successful innovating in problem solving (Liker and Bókony 2009). We recognize that we should conduct experiments to prove our hypothesis. A series of experiments are being planned when our campus reopens.

Acknowledgments

We thank Raúl Pérez-Rodríguez, which provided us with some information, Jaime A. Collazo and two other anonymous reviewers which offered valuable suggestions to improve this work.

\section{Literature Cited}

Amo, L., I. Galván, G. Thomas, and J. J. Sanz. Predator odour recognition and avoidance in songbirds. Functional Ecology 22(2):289-293. https://doi.org/10.1111/j.1365-2435.2007.01361.x

Chater, K. F. 2015. The smell of soil. Microbiology Today 42(2):66-69. https://microbiologysociety.org/publication/past-issues/soil/article/the-smell-of-the-soil.html

Danforth, S. 1926. Birds of Cartagena Lagoon, Porto Rico. Journal of the Department of Agriculture Porto Rico 10:1-36.

Deveraux, C. L., M. J. Whittingham, J. R. Krebs, E. Fernández-Juricic, and J. A. Vickery. 2006. What attracts birds to newly mown pasture? Decoupling the action of mowing from the provision of short swards. Ibis 148:302-306. https://doi.org/10.1111/j.1474-919X.2006.00533.X 
Ducatez, S., J. N. Audet, and L. Lefebre. 2015. Problem-solving and learning in Carib grackles: individuals show a consistent speed-accuracy trade-off. Animal Cognition 18:485-496. https://doi.org/10.1007/s10071-014-0817-1

Gill, F. and D. Donsker (Editors). 2019. Oropendolas, orioles, blackbirds. IOC World Bird List Version 10.1. International Ornithologists' Union. Retrieved June 13, 2020. https://www.worldbirdnames.org/bow/blackbirds/

Keith, A. R., J. W. Wiley, S. C. Latta, and J. A. Ottenwalder. 2003. The Birds of Hispaniola, Haiti and the Dominican Republic: An Annotated Checklist. British Ornithologists' Union. Checklist Series 21. Natural History Museum. London, England, UK. 293 pp.

Lack, D. 1976. Island Biology, Illustrated by the Land Bird of Jamaica. University of California Press. Berkeley, California, USA. 445 pp. https://doi.org/10.2307/2418771

Lefebvre, L., S. Ducatez, and J. N. Audet. 2016. Feeding innovations in a nested phylogeny of Neotropical passerines. Philosophical Transactions of the Royal Society of London-Biological Science 371(1690):20150188. https://doi.org/10.1098/rstb.2015.0188

Liker, A. and V. Bókony. 2009. Larger groups are more successful in innovative problem-solving inhouse sparrows. Proceedings of the National Academy of Sciences of the USA 106 (19) 78937898. https://doi.org/10.1073/pnas.0900042106

Mardon, J., A. P. Nesterova, J. Traugott, S. M. Saunders, and F. Bonadonna. 2010. Insight of scent: experimental evidence of olfactory capabilities in the wandering albatross (Diomedea exulans). Journal of Experimental Biology 213:558-563. https://doi.org/10.1242/jeb.032979

Morrand-Ferron, J., L. Lefebvre, S.M. Reader, D. Sol, and S. Elvin. 2004. Dunking behavior in Carib grackles. Animal Behavior 68:12671274. https://doi.org/10.1016/j.anbehav.2004.01.016

Morrand-Ferron, J., M. Veillette and L. Lefebvre. 2006. Stealing of dunked food in Carib grackles (Quiscalus lugubris). Behavioral 73:342-347. https://doi.org/10.1016/j.beproc.2006.08.006

Oberle, M. 2010. Puerto Rico's Birds in Photographs. Third Edition. Editorial Humanitas. San Juan, Puerto Rico. 132 pp.

Overington, S. E., J. Morand-Ferron, N. J. Boogert and L. Lefebvre. 2009. Technical innovations drive the relationship between innovativeness and residual brain size in birds. Animal Behavior 78:1001-1010. https://doi.org/10.1016/j.anbehav.2009.06.033

Pérez-Rivera, R. A. 2000. Alimento y conducta alimentaria, no informada, del Mozambique de Puerto Rico (Quiscalus niger brachypterus). El Pitirre (USA) 13:40-41.

Pérez-Rivera, R. A. 2018. Important plants for urban birds in Puerto Rico after the impact of a severe hurricane. Equilibrium (Humacao, Puerto Rico) 2:20-34.

Pérez-Rivera, R. A. 2019. Use of millipedes as food and for self-anointing by the Puerto Rican Grackle (Quiscalus niger brachypterus). Ornitología Neotropical 30:69-71.

Pollonara, E., P. Luschi, T. Guilford, M. Wikelski, F. Bonadonna, and A. Gagliardo. 2015. Olfaction and topography, but not magnetic cues, control navigation in a pelagic seabird: displacements with shearwaters in the Mediterranean Sea. Scientific Report 5:16486. https://doi.org/10.1038/srep16486

Raffaele, H., J. W. Wiley, O. Garrido, A. R. Keith, and J. Raffaele. 1998. A Guide to the Birds of the West Indies. Princeton University Press. Princeton, New Jersey, USA. 511 pp.

Reader S. M., J. Morand-Ferron, I. M. Côté, and L. Lefebvre. 2003. Unusual feeding behavior in six species of Barbadian birds. El Pitirre (USA) 15:117-120.

Rivera Cianchini, O. and L. Mojica Sandoz. 1981. Pájaros Notables de Puerto Rico. Editorial de la Universidad de Puerto Rico. San Juan, Puerto Rico. 164 pp.

Schnee, C., T. G. Köllner, M. Held, T. C. J. Turlings, J. Gershenzon, and J. Degenhardt. 2006. The products of a single maize sesquiterpene synthase form a volatile defense signal that attracts natural enemies of maize herbivores. Proceedings of the National Academy of Sciences of the USA 103(4):1129-1134. https://doi.org/10.1073/pnas.0508027103

Steiger, S. S., A. Fiedler, M. Valcu, and B. Kempenaers. 2008. Avian olfactory receptor gene repertoires: evidence for a well-developed sense of smell in birds? Proceedings of The Royal Society B Biological Sciences 275:2309-2317. https://doi.org/10.1098/rspb.2008.0607 
Vickery, J. A., J. R. Tallowin, R. E. Feber, E. J. Asteraki, P. W. Atkinson, R. J. Fuller, and V. K. Brown, 2001. The management of lowland neutral grasslands in Britain: effects of agricultural practices on birds and their food resources. Journal of Applied Ecology 38:647-664. https://doi.org/10.1046/j.1365-2664.2001.00626.x

Wetmore, A. 1916. Birds of Porto Rico. United States Department of Agriculture (USDA). Bulletin Number 326. 140 pp. https://doi.org/10.5962/bhl.title.64703 